\title{
MOGUĆNOSTI ISPITIVANJA KAPILARNOG UPIJANJA NA MIKROJEZGRIMA
}

\author{
Arpad $\check{C}^{1}{ }^{1}$ \\ Josip Kovač Striko ${ }^{2}$ \\ Dragana Tabaković ${ }^{3}$
}

UDK: 624.012.45:620.1

DOI: 10.14415/zbornikGFS29.02

Rezime: Prilikom dijagnostike stanja armirano betonske konstrukcije sa aspekta ocene trajnosti betona postojeće metode uglavnom koriste rezultate ispitivanja dobijene sofisticiranom i skupocenom opremom, koji nisu univerzalnog karaktera, tj. mogu se koristiti samo za jedan segment ocene trajnosti betona. Na taj način svaka dodatna informacija o stanju betona je dragocena, pogotovo ako ne zahteva dodatno ispitivanja sa posebom opremom. Ispitivanja betonskih i AB konstrukcija vađenjem mikrojezgara se smatra poludestruktivnom metodom, koja neznatno oštećuje samu konstrukciju, a koristi se prvenstveno za ispitivanje karbonatizacije, zapreminske mase i upijanja betona.

U radu su predstavljeni rezultati ispitivanja kapilarnom upijanja prema SRPS EN 480-5 na standardnim uzorcima i na mikrojezgrima izvađenim iz uzoraka oblika kocke sa dužinama ivica $20 \mathrm{~cm}$. Takođe su predstavljeni i rezultati ispitivanja penetracije vode pod pritiskom na istim uzorcima, na kojima su prethodno uzorkovana mikrojezgra.

Ova ispitivanja su urađena na betonima sa zahtevanom projektovanom mešavinom za najzahtevnije klase izloženosti prema EN 206-1 i koristeći razne dodatke koji je poznato da utiču strukturu pora $i$ samim tim i na trajnost očvrslog betona.

Ključne reči: kapilarno upijanje, mikrojezgra, trajnost betona

\section{UVOD}

Ocena trajnost betona je veoma kompleksna i kako bi bila sveobuhvatna potrebno je sagledati više parametara [1], [2]. Oni se mogu grupisati u:

- $\quad$ parametre koje su vezani za ocenu otpornosti betona prema prodoru hlorida

- metode za definisanje otpornosti betona pri prodoru različitih gasova (pre svega kisonik, vazduh i ugljen dioksid)

- metode za merenje otpora betona pri provođenju struje

- $\quad$ i različite metode za ispitivanje otpornosti betona pri prodiranju vode

\footnotetext{
${ }^{1}$ Arpad Čeh,dipl.inž.građ.,Građevinski fakultet Subotica, Kozaračka 2a, tel:024/554-300, e-mail: ceh@gf.uns.ac.rs

${ }^{2}$ Josip Kovač Striko, dipl.inž.građ.,Građevinski fakultet Subotica, Kozaračka 2a, tel:024/554-300, e-mail:josip.kovacstriko@gmail.com

${ }^{3}$ Dragana Tabaković, dipl.inž.građ.,Građevinski fakultet Subotica, Kozaračka 2a, tel:024/554-300, e-mail:dragana.tabakovic@gmail.com
} 
Metode koje se koriste pri oceni različitih aspekata otpornosti betona se ubrzano razvijaju kako je otpornost betonskih, a pre svega armirano betonskih i prednapregnutih $A B$ konstrukcija postala važna i sa aspekta održivog razvoja. Projektovanje trajnjih, kvalitetnijih betonskih konstrukcija postaje veoma važan zahtev kod novih objekata, pogotovo ako je njihov eksploatacioni vek duži od 50 godina [3]. A ocena trenutnog stanja postojećih betonskih konstrukcija sa aspekta trajnosti predstavlja ponekad još i veći izazov. Pre svega je naravno, važno sagledati sve moguće uticaje koji mogu štetnu oticati na beton ili na armaturu u betonu, ali često utvđivanje relevantnih parametara je limitirano, pošto se uglavnom radi o veoma skupim i sofisticiranim metodama. U tim slučajevima, kada su ograničena novčana sredstva za moguća ispitivanja važno je još imati u vidu i to, da ne samo parametri grupisani u gore navedenim grupama nego i unutar tih grupa različite metode nisu u većini slučajeva u korelaciji. Na primer: ako beton poseduje visoku klasu otpornosti na prodor vode pod pritiskom, to ne mora da znači da je on veoma otporan i na prodor hlorida. Jedan od tih slučajeva je i da, posmatrajući samo otpornost betona na prodor vode, utvrđivanje dubine penetracije vode pod pritiskom (ili vodonepropustljivost betona), ne mora da bude u korelaciji sa kapilarnim upijanjem betona. Standardne metode, koje se koriste za merenje ove dve karakteristike betona su destruktivne.

Ispitivanja betonskih i AB konstrukcija vađenjem mikrojezgara se smatra poludestruktivnom metodom, koja neznatno oštećuje samu konstrukciju, a koristi se prvenstveno za ispitivanje karbonatizacije, zapreminske mase i upijanja betona (ukupne apsorpcije) (slika 1).

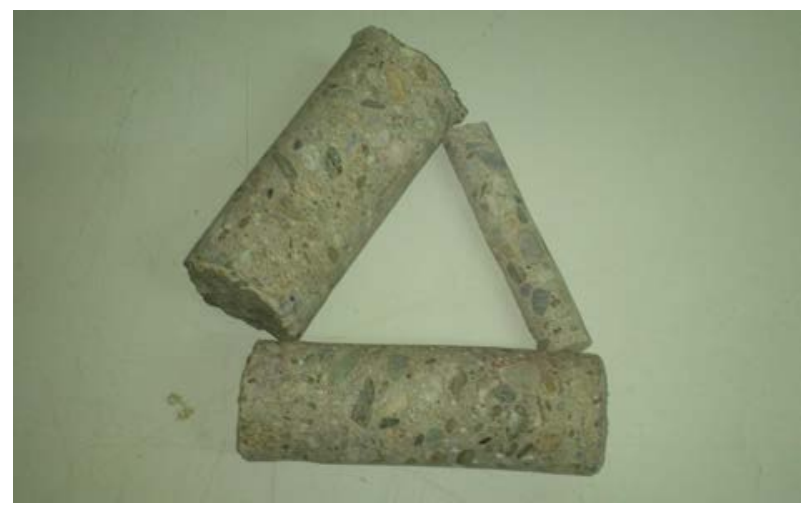

Slika 1. Mikrojezgra različitih prečnika

Prednosti mikrojezgara su u tome da i u gusto armiranom betonu se mogu izvaditi uzorci betona bez armaturnog čelika ili tkzv. neoštećeni uzorci. Isto je ponekad prosto nemoguće postići sa jezgrima betona standardnih dimenzija koja se uzimaju iz postojeće konstrukcije. Ideja je bila da se na mikrojezgrima uradi ispitivanje kapilarnog upijanja vode, prema SRPS EN 480-5 [4] na standardnim uzorcima i na mikrojezgrima izvađenim iz uzoraka oblika kocke sa dužinama ivica $20 \mathrm{~cm}$. Takođe su predstavljeni i rezultati ispitivanja penetracije vode pod pritiskom na istim uzrocima, na kojima su prethodno uzorkovana mikrojezgra. Pošto standard SRPS EN 480-5 predviđa ispitivanje na uzorcima oblika prizme $4 \times 4 \times 16 \mathrm{~cm}$, odlučili smo se za vađenje mikrojezgara prečnika $42 \mathrm{~mm}$ iz uzoraka oblika kocke dimenzija 20x20x20cm. 


\section{MATERIJAL I ISPITIVANJA}

U radu su prezentovani rezultati analize kapilarnog upijanja i vodonepropustljivosti na betonima različitih sastava, što je podrazumevalo varijacije vrste cementa i različitih aditiva. Koristili smo agregat rečnog porekla "Moravac". Sve mešavine su pravljene sa maksimalnim zrnom agregata od $8 \mathrm{~mm}$, sa dvofrakcijskom kompozicijom. To je izabrano iz razloga kako bi se smanjio uticaj veličine zrna na ispitivanja na izvađenim mikrojezgrima. Uzorci beona sa mešavinom oznake 1 su pravljeni sa čisim portlan cementom CEM I 52.5N. Kod mešavine sa oznakom 2 korisili smo sulfatnootporni cement CEM III/B 32.5S, kod mešavine 3 CEM II/A-M (S-L) 42.5R, a kod mešavine 4

CEM II/A-M (V-L) 42.5R. Kod mešavina od 5-9 koristili smo različite dodatke koji utiču na poroznost betona i to: kod mešavine 5 hiperplastifikator na bazi polikarboksilata, mešavina 6 je isto sa dodatkom hiperplastifikatora ali na bazi naftalen sulfonata, mešavina 7 je pravljena sa dodatkom silikatne čađi, mešavina 8 je bila sa dodatkom metakaolina, a 9. mešavina je imala kombinaciju dodataka silikatne čađi i metakaolina 50-50\%. Recepture betonskih mešavina su date u tabeli 1:

Tabela 1. Kompozicije betonskih mešavina

\begin{tabular}{|l|l|l|l|l|l|}
\hline Oznaka & $\begin{array}{l}\text { Cement } \\
{\left[\mathrm{kg} / \mathrm{m}^{3}\right]}\end{array}$ & $\begin{array}{l}\text { Voda } \\
{\left[\mathrm{kg} / \mathrm{m}^{3}\right]}\end{array}$ & $\begin{array}{l}\text { Agregat 0/4 } \\
{\left[\mathrm{kg} / \mathrm{m}^{3}\right]}\end{array}$ & $\begin{array}{l}\text { Agregat 4/8 } \\
{\left[\mathrm{kg} / \mathrm{m}^{3}\right]}\end{array}$ & $\begin{array}{l}\text { Aditiv } \\
{\left[\mathrm{kg} / \mathrm{m}^{3}\right]}\end{array}$ \\
\hline 1 & 450 & 225 & 1018 & 598 & - \\
\hline 2 & 450 & 225 & 1018 & 598 & - \\
\hline 3 & 450 & 225 & 1018 & 598 & - \\
\hline 4 & 450 & 225 & 1018 & 598 & - \\
\hline 5 & 450 & 152 & 1115 & 651 & 5,5 \\
\hline 6 & 450 & 152 & 1115 & 651 & 5,5 \\
\hline 7 & 405 & 225 & 1018 & 598 & 45 \\
\hline 8 & 405 & 225 & 1018 & 598 & 45 \\
\hline 9 & 405 & 225 & 1018 & 598 & 45 \\
\hline
\end{tabular}

Od opitnih betona različitih mešavina napravljeni su, dakle uzorci betona oblika prizme i kocke sa gore navedenim dimenzijama. Uzorci su negovani u vodi do starosti betona od 28 dana. Nakon obrade i kondicioniranja uzorci oblika prizme su izmerena kapilarna upijanja vode prema SRPS EN 480-5 nakon 7 i 90 dana. Na uzorcima oblika kocke, dimenzija 20x20x20 cm su prvo izvađena mikrojezgra prečnika $42 \mathrm{~mm}$ na dovoljnoj udaljenosti od povšine na kojoj je kasnije izmerena dubina penetracije vode pod pritiskom prema standardu SRPS EN 12390-8 (Slika 2.)[5].

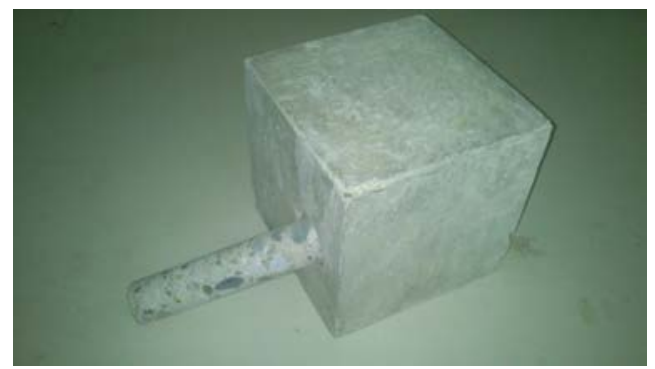

Slika 2. Uzorak mikrojezgra izvađen iz uzorka za ispitivanje vodonepropustljivosti 
Nakon toga je na mikrojezgrima ispitano kapilarno upijanje merenjem takođe vrednosti nakon 7 i 90 dana.

\section{REZULTATI}

Rezultati ispitivanja kapilarnog upijanja na referentnim uzorcima i na uzorcima mikrojezgara su prikazani na slici 3. Zajedno su prikazani rezultati upijanja nakon 7 i 90 dana za obe vrste uzoraka.

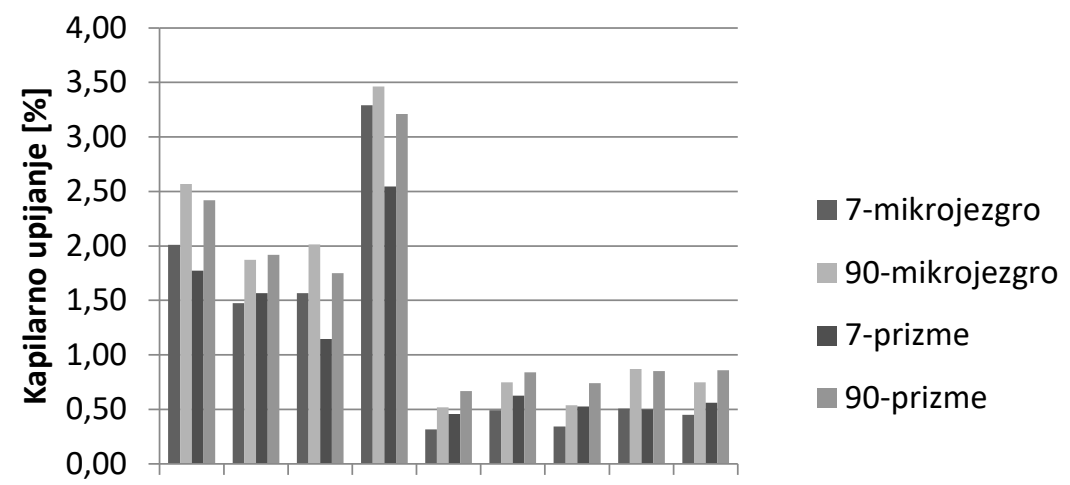

A 2 SS 2 SL 2 H 2 P1 2 P2 2 SF 2 AK 2SA 2

\section{Oznaka}

Slika 3. Rezultati ispitivanja kapilarnog upijanja na standardnim uzorcima i na mikrojezgrima

Na slici 4 su prikazani rezultati ispitivanja dubine penetracije vode pod pritiskom prema standardu SRPS EN 12390-8.

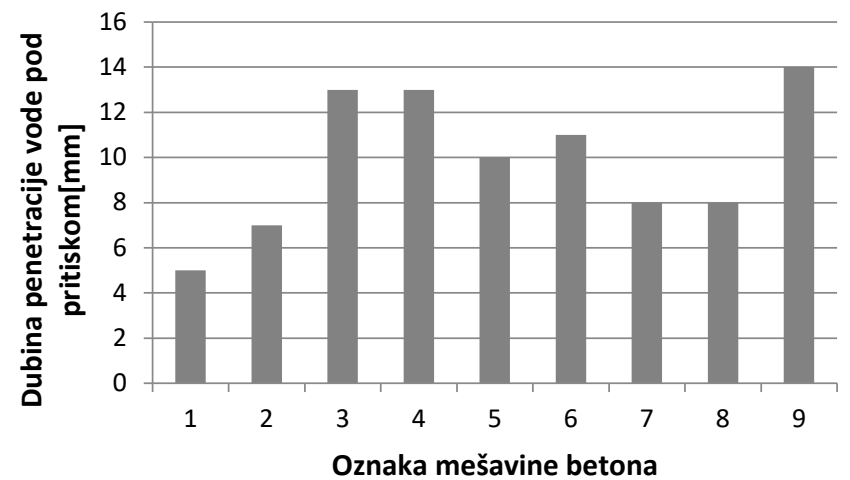

Slika 4. Rezultati ispitivanja dubine penetracije vode pod pritiskom 


\section{ZAKLJUČAK}

$\mathrm{Na}$ osnovu rezultata se može zaključiti da ispitivanje kapilarnog upijanja na mikrojezgrima je dalo veoma slične rezultate kao i na standardnim uzorcima prema SRPS EN 480-5. Kod mešavina betona sa oznakama od 5 do 9, gde je primenjena mera smanjenja poroznosti na fizički (potem smanjenja vodocementnog faktora) ili na hemijski način (putem reaktivnih dodataka silikatne čađi ili metakaolina) kapilarno upijanja je i nakon 7 i nakon 90 dana, na obe vrste uzoraka ispod $1 \%$. Kod ostalih uzoraka je veće upijanje. Ovaj rezultat opravdava dalja ispitivanja u ovom pravcu, jer bi se ispitivanje kapilarnog upijanja, kao esencijalnog za ocenu trajnosti betonske konstrukcije [6], moglo uraditi i na mikrojezgrima, što bi značilo višestruku racionalizaciju i na broju metoda i na broju uzoraka, potrebnih za dijagnostiku stanja.

Ispitivanje dubine penetracije vode pod pritiskom prema standardu SRPS EN 12390-8 daje veoma različite rezultate od rezultata kapilarnog upijanja. Radi sveobuhvatne slike o trajnosti betona, se ne može napraviti komparacija između ove dve metode.

\section{ЛИТЕРАТУРА}

[1] Bešević, M., Abdulaj, B.: Sanacija, adaptacija i dogradnja, rezidencijalne vile u Bulevaru Mira u Beogradu, Problem izgradnje i vrednovanja objekta, Građevinski fakultet, Beograd, Aranđelovac, 2000. , 307-314

[2] Bešević, M., Vlajić, Lj.: Sanacija, adaptacija i dogradnja objekta u NEmanjinoj ulici br.9 u Beogradu, DGKS-13. Kongres, Zlatibor-Čigota, 2010, 445-452

[3] Bešević, M., Gajić, M.: Sanacija armirano betonske konstrukcije poslovnog objekta u Crnotravskoj ulici 2. Beograd, Simpozijum Vrnjačka banja 19-21, 2012 - DGKS, 53-58

[4] SRPS EN 480-5: 2010 - Dodaci betonu, malteru i injekcionoj masi - Metode ispitivanja - Deo 5: Određivanje kapilarnog upijanja

[5] SRPS EN 12390-8:2010 - Ispitivanje očvrslog betona - Deo 8: Dubina penetracije vode pod pritiskom

[6] Martys, N.S., Ferraris, C.F.: Capillary transport in mortars and concrete. Cement and Concrete Research, 1997., vol. 27, No. 5, pp. 747-760

\section{POSSIBILITIES OF TESTING CAPILLARY ABSORPTION ON MICROCORES}

Summary: During inspection of reinforced concrete structures from the aspect of durability evaluation of concrete, the present methods generally use the test results obtained by the sophisticated and expensive equipment, which are usually not universal purpose, ie. they can be used only for one segment of durability evaluation of the concrete. This way any additional information about the condition of concrete is valuable, especially if it is not require an additional testing with special equipment. Tests of concrete and reinforced concrete with microcore drilling is considered to be a semi- destructive 
method, which slightly damages the structure itself, and it is primarily used for testing carbonation, density and absorption of concrete.

The paper presents the results of capillary absorption according to SRPS EN 480-5 on standard-size samples and on the microcores extracted from cube form samples with edge length of $20 \mathrm{~cm}$. In the article the testing results of penetration of water under pressure are also presented on the same samples, on which we previously gained microcores.

These tests were carried out on with concrete mixtures designed for the most demanding exposure classes according to EN 206-1 and using a variety of additives that are known to affect the structure of pores and consequently also the durability of a hardened concrete.

Keywords: capillary absorption, microcores, durability of concrete 